\title{
Profile of the graduates of the phd course of the postgraduate program in physical education: a case study at Federal University of Santa Catarina (2006 to 2018)
}

\section{Perfil dos egressos do doutorado em educacão física: um estudo de caso na Universidade Federal de Santa Catarina (2006 a 2018)}

\author{
Sofia Wolker Manta ${ }^{1}$ \\ (D) https://orcid.org/0000-0002-1059-2471 \\ Paula Fabricio Sandreschi ${ }^{1}$ \\ (1) https://orcid.org/0000-0001-6487-2359 \\ Allana Alexandre Cardoso ${ }^{1}$ \\ (D) https://orcid.org/0000-0002-0280-7567 \\ Tânia Rosane Bertoldo Benedetti ${ }^{1}$ \\ (D) https://orcid.org/0000-0002-2035-5082 \\ Gelcemar Oliveira Farias ${ }^{1,2}$ \\ (iD https://orcid.org/0000-0003-3552-3437 \\ Rui Resende ${ }^{1,3}$ \\ (D) https://orcid.org/ 0000-0003-4314-0743 \\ Juarez Vieira do Nascimento \\ (1) https://orcid.org/0000-0003-0989-949X
}

Abstract - The aim of the study was to analyze the graduate's profile of the $\mathrm{PhD}$ course in Postgraduate Program in Physical Education (PPPE), Federal University of Santa Catarina. Information from the $92 \mathrm{PhD}$ graduates from 2006 to 2018 was collected from secondary sources of public domain sites. Three independent evaluators filtered the information through double typing. The data revealed that more than $50 \%$ of the graduates were male, $58.7 \%$ had a scholarship, and $27.8 \%$ had a sandwich doctorate in foreign institutions. Only $17.4 \%$ of graduates completed postdoctoral training. The highest proportion has employment as effective teachers $(73.3 \%)$, mainly in public higher education institutions. The concentration themes in the area of Physical Activity and Health (PAH) predominate in the titles of the conclusion work. During the formative trajectory, $48.9 \%$ of the graduates changed, at least, once in the concentration area, $44.6 \%$ remained in the same area and $6.5 \%$ investigated the three distinct concentration areas during undergraduate, masters and doctoral studies. The majority develop PAH (50.0\%), followed by Pedagogical (25.5\%) and Biodynamics and Human Performance (17.8\%). Thus, the doctors training in PPPE seems to design a profile according to the idealized by the course, with professional possibilities of insertion in higher education and engagement in scientific investigations.

Key words: Graduates; Higher education; Professional qualification; Physical education.

Resumo - O objetivo do estudo foi analisar o perfil dos egressos do curso de doutorado do Programa de Pós-graduação em Educação Física (PPGEF), da Universidade Federal de Santa Catarina. As informaçôes dos 92 egressos do doutorado no periodo de 2006 a 2018 foram levantadas em fontes secundárias de sites de dominio público. Três avaliadores independentes filtraram as informaçôes por meio de dupla digitação. Os resultados revelaram que mais de 50,0\% dos egressos eram do sexo masculino, $58,7 \%$ tiveram bolsa de estudos e $27,8 \%$ realizaram estágio de doutorado sanduíche em instituiçôes estrangeiras. Apenas 17,4\% dos egressos concluíram estágio de pós-doutorado. A maioria tem vinculo empregaticio como professor efetivo (73,3\%), principalmente em instituiçôes públicas do magistério superior. As temáticas da área de concentração em Atividade Física e Saúde (AFS) predominam nos títulos dos trabalhos de conclusão. Ao longo da trajetória formativa, 48,9\% ( $n=45)$ dos egressos mudaram pelo menos uma vez de área de concentração, 44,6\% (n=41) mantiveram-se na mesma área de concentração e 6,5\% (n=6) investigaram as três distintas áreas de concentração durante a graduação, mestrado e doutorado. A maioria dos egressos desenvolve pesquisas na área de AFS (50,0\%), seguido da Pedagógica (25,5\%) e Biodinâmica do Desempenho Humano (17,8\%). Assim, a formação de doutores no PPGEF parece desenhar um perfil de acordo com o idealizado pelo curso, com chances profissionais de inserção no ensino superior e com engajamento em investigaçôes cientificas.

Palavras-chave: Educação física; Ensino superior; Egressos; Formação profissional.
1 Universidade Federal de Santa Catarina. Centro de Desportos. Programa de Pós-graduação em Educação Física. Florianópolis, SC. Brasil.

2 Universidade do Estado de Santa Catarina. Centro de Ciências da Saúde e do Esporte. Florianópolis, SC. Brasil.

3 University Institute of Maia. Portugal.

Received: 15 July 2019 Accepted: 13 November 2019

How to cite this article Manta SW, Sandreschi PF, Cardoso AA, Benedetti TRB, Farias GO, Resende R, Nascimento JV. Rev Bras Cineantropom Desempenho Hum 2020, 22:e66261. DOl: http://dx.doi.org/10.1590/19800037.2020v22e66261

Copyright: This work is licensed under a Creative Commons Attribution 4.0 International License. 


\section{INTRODUCTION}

The postgraduate course in Brazil, implemented since 1965, has been consolidated in the university scope by offering master's and doctoral courses ${ }^{1}$. The National Postgraduate System covers several areas in different branches of knowledge, qualifying young scientists, researchers and teachers as a means to contribute to the country's technological and scientific plan ${ }^{1,2}$. The National Postgraduate System is governed by the Coordination for the Improvement of Higher Education Personnel (CAPES in the Portuguese acronym), which is responsible for the evaluation of new courses and also for monitoring the programs ${ }^{1-3}$.

To optimize the management of the activities assigned to CAPES, the knowledge areas are grouped into Colleges (first level) and Large Areas (second level). Thus, composing the College of Life Sciences, in the Great Area of Health Sciences, is the Area 21 (or Physical Education Area), composed in sub-areas of academic and professional performance of Speech Therapy, Physical Therapy and Occupational Therapy, besides Physical Education ${ }^{4}$. The subarea of Physical Education has the highest number of courses compared to the others in Area 21, consisting of 35 academic masters, three professional masters, 22 academic doctorates and a professional doctorate. These courses comprise 38 post-graduate programs, distributed in 29 public universities, two of which have two or more programs, and five of the private education network ${ }^{4,5}$.

The developments in the scientific community are evident, both in the evaluation of the programs and the research resulting from these programs ${ }^{6}$. One of the issues that make up the program evaluation system is the graduates, whose evaluation is important to analyze and monitor them insertion in the labor market (public or private), scientific and academic production ${ }^{5}$.

Some evidences reveal that graduates of physical education programs perceive their education with evidence in research, followed by preparation for teaching in higher education ${ }^{7}$. In this way, studies show the interest of the programs in the systematic follow-up of graduates, in order to establish curricular reorganization, future work strategies, their satisfaction with programs, among other factors that are relevant to education ${ }^{8-10}$.

One aspect to highlight is the professional trajectory importance after the doctorate course, since this is the highest degree of academic qualification and last stage of formation that precedes the transition to university teaching career ${ }^{11,12}$. The geographical centralization of the Physical Education Programs in the South and Southeast regions, which bring together 26 of the 38 existing programs ${ }^{13}$ also are referred. Considering that Brazilian production of scientific knowledge is closely linked to the stricto sensu postgraduation in the country ${ }^{14}$, nucleation - that is, insertion of new doctors in postgraduate courses or groups of active research are distinct from those who formed them. This plays an important role in the success of Brazilian higher education, highlighting the graduates of $\mathrm{PhD}$ courses as important agents of dissemination and production of knowledge. 
Physical education trained doctors $(n=184)$ in programs at the southern region of the country, about $22.3 \%$ are enrolled in public educational institutions, acting as teachers and coordinators of research projects ${ }^{11}$. However, is clear a fragility of studies that have evaluated the profile of these graduates, mainly in areas of the conclusion work, academic exchange during training, access to scholarships, as well in the formative trajectory to research areas of physical education. In this context, the aim of the present study was analyzing the graduates' profile in the doctoral program at Postgraduate Program in Physical Education of the Federal University of Santa Catarina.

\section{METHOD}

The study has a qualitative-quantitative approach to data, as descriptive with a case study-like design. The Federal University of Santa Catarina, specifically of the Postgraduate Program in Physical Education was selected to analyze the graduates' profile in the doctoral program, which began in the year of 1996 with the implementation of the master's degree and in 2006 with the first doctorate group.

From 1996 to 2016, 373 students joined in the master's course and 92 in the doctoral program. In the 2013-2016 quadrennial evaluation, this program was evaluated with note 6 by CAPES, which denotes a scenario of stability, maturity and quality, in the training of doctor-masters, strengthening the production of knowledge and innovation in the areas of health, sport ${ }^{5}$.

The collection of information used secondary data sources available on public domain websites. On the Postgraduate Program in Physical Education website, the list of new entrants to the doctoral program since 2006 was obtained, as well as those who defended their thesis until the year 2018 (third quarter). This list contained in detail the name of the postdoc, guidance counselor, assessment bank, thesis title and defense date (http:// ppgef.ufsc.br/noticias/). Next, the entry year and completion of the course was consulted on the website of the Federal University of Santa Catarina Egress Monitoring System (https://egressos.sistemas.ufsc.br/listaEgressos. xhtml). All the above information was compiled in a Microsoft Excel ${ }^{\circledR}$ worksheet to compose the database.

Another data source used was the Lattes platform (http://lattes.cnpq. $\mathrm{br} /$ ) to verify the academic graduates' curricula in the $\mathrm{PhD}$. The information was previously established and, from the consultation to the curriculum, data were collected referring to sex, concentration area, scholarship, year of completion of the courses (undergraduate, masters, doctorate and postdoctoral) year of engagement, functional framework (effective or substitute teacher, administrative technician, autonomous and/or collaborator), topics of the titles of the conclusion papers (monographs, dissertation and thesis), research projects in progress and the form of participation (coordinator, and/or member). The information was collected in October and November 
of 2018 by three independent evaluators. The conference of the information was operationalized by means of double typing. The data were transferred and analyzed by the statistical software IBM SPSS ${ }^{\circledR}$ version 21 , by means of absolute and relative frequency.

\section{RESULTS}

The study included 92 graduates in the $\mathrm{PhD}$ from the Postgraduate Program in Physical Education of the Federal University of Santa Catarina who had joined in the period from 2006 to 2018. Of these, more than 60\% of the graduates finished their undergraduate courses between 2000 and 2010, while 29.4\% finished the course of master's degrees between 2010 and 2014. The average time of completion of the course was 45.7 months $( \pm 9.1)$, more than $50 \%$ were male and approximately six out of 10 took the $\mathrm{PhD}$ course with a scholarship. During the course, 30.4\% completed a $\mathrm{PhD}$ exchange in foreign institutions (Table 1). Regarding the origin of foreign institutions, $38.5 \%$ of the graduates went to Portugal, $11.5 \%$ to the United States, $11.5 \%$ to Canada, $11.5 \%$ to Italy, $11.5 \%$ to England, $7.7 \%$ for Spain, 3.8\% for France and 3.8\% for New Zealand. It should be noted that $17.4 \%(n=15)$ joined in postdoctoral programs and, for the most part, with scholarship ( $\mathrm{n}=13,86.7 \%)$.

Table 1. Characteristics of the PhD graduates. Post-graduation Program in Physical Education, Federal University of Santa Catarina, 2018.

\begin{tabular}{|c|c|c|}
\hline Academic profile & $n$ & $\%$ \\
\hline \multicolumn{3}{|l|}{$\operatorname{Sex}(n=92)$} \\
\hline Female & 40 & 43.5 \\
\hline Male & 52 & 56.5 \\
\hline \multicolumn{3}{|l|}{ PhD admission period $(n=92)$} \\
\hline 2006 to 2010 & 27 & 29.3 \\
\hline 2011 to 2014 & 65 & 70.7 \\
\hline \multicolumn{3}{|l|}{ PhD completion period $(n=92)$} \\
\hline 2009 to 2014 & 45 & 48.9 \\
\hline 2015 to 2018 & 47 & 51.1 \\
\hline \multicolumn{3}{|l|}{ Scholarship of PhD $(n=92)$} \\
\hline No & 38 & 41.3 \\
\hline Yes & 54 & 58.7 \\
\hline \multicolumn{3}{|l|}{ PhD exchange $(n=92)$} \\
\hline No & 64 & 69.6 \\
\hline Yes & 28 & 30.4 \\
\hline PhD exchange in foreign institutions $(n=28)$ & 26 & 92.9 \\
\hline \multicolumn{3}{|l|}{ Postdoctoral achievement $(n=92)$} \\
\hline No & 74 & 80.4 \\
\hline Yes & 15 & 17.4 \\
\hline In progress & 02 & 01.1 \\
\hline Interrupted & 01 & 01.1 \\
\hline
\end{tabular}


.. continue

\begin{tabular}{lll}
\hline Academic profile & $n$ & $\%$ \\
\hline Postdoctoral institution $(n=18)$ & 13 & 72.2 \\
Brazilian & 05 & 27.8 \\
Foreign & & \\
Scholarship of postdoctoral $(n=18)$ & 01 & 5.6 \\
\hline No & 13 & 72.2 \\
Yes & 04 & 22.2 \\
Does not especify & & \\
Master's degree (n=92) & 07 & 07.6 \\
1988 to 1999 & 58 & 63.0 \\
2000 to 2009 & 27 & 29.4 \\
2010 to 2014 & & 30.4 \\
Scholarship of masters $(n=92)$ & 28 & 69.6 \\
\hline No & 64 & 39.1 \\
\hline Yes & & 60.9 \\
\hline Graduation completion period $(n=92)$ & 36 & \\
\hline 1977 to 1999 & 56 & \\
\hline 2000 to 2010 & & \\
\hline
\end{tabular}

Source: The authors.

Most of the $\mathrm{PhD}$ graduates have an effective teaching job in teaching institutions $(73.3 \%, n=66)$. Of these, more than $80 \%$ work in the public higher education teaching profession (Table 2). Still, 13 (24.5\%) of the effective teachers are also collaborators as researchers in other institutions.

Table 2. Employee relationship and functional framework of the graduates of the PhD. Program of the Post-Graduation Program in Physical Education, Federal University of Santa Catarina, $2018(\mathrm{n}=92)$.

\begin{tabular}{|c|c|c|c|c|c|c|c|c|c|c|c|c|c|c|}
\hline \multirow{3}{*}{$\begin{array}{l}\text { Employee } \\
\text { relationship }\end{array}$} & \multicolumn{14}{|c|}{ Functional framework } \\
\hline & \multicolumn{2}{|c|}{$\begin{array}{c}\text { Effective } \\
\text { teacher } \\
(n=66)\end{array}$} & \multicolumn{2}{|c|}{$\begin{array}{l}\text { Collaborator } \\
\qquad(n=8)\end{array}$} & \multicolumn{2}{|c|}{$\begin{array}{l}\text { Substitute } \\
\text { teacher } \\
(n=7)\end{array}$} & \multicolumn{2}{|c|}{$\begin{array}{l}\text { Admnistrative } \\
\text { technician } \\
(n=1)\end{array}$} & \multicolumn{2}{|c|}{$\begin{array}{c}\text { Without } \\
\text { employment } \\
\text { relationship } \\
(n=2)\end{array}$} & \multicolumn{2}{|c|}{$\begin{array}{l}\text { Service } \\
\text { provider } \\
(n=2)\end{array}$} & \multicolumn{2}{|c|}{$\begin{array}{l}\text { Unspecified } \\
\qquad(\mathrm{n}=4)\end{array}$} \\
\hline & $\mathrm{n}$ & $\%$ & $n$ & $\%$ & $\mathrm{n}$ & $\%$ & $\mathrm{n}$ & $\%$ & $n$ & $\%$ & $n$ & $\%$ & $n$ & $\%$ \\
\hline Public IHE & 53 & 80.3 & 7 & 87.5 & 6 & 85.71 & 1 & 100.0 & 1 & 50.0 & - & - & - & - \\
\hline Foreign instituions & 1 & 1.52 & 1 & 12.5 & - & - & - & - & - & - & - & - & - & - \\
\hline Federal Institutes & 5 & 7.58 & - & - & - & - & - & - & - & - & - & - & - & - \\
\hline Private IHE & 6 & 9.09 & - & - & 1 & 14.29 & - & - & 1 & 50.0 & - & - & 1 & 25.0 \\
\hline Private schools & - & - & - & - & - & - & - & - & - & - & 1 & 50.0 & - & - \\
\hline Public schools & 1 & 1.52 & - & - & - & - & - & - & - & - & - & - & - & - \\
\hline Freelance & - & - & - & - & - & - & - & - & - & - & 1 & 50.0 & - & - \\
\hline Unspecified & - & - & - & - & - & - & - & - & - & - & - & - & 3 & 75.0 \\
\hline
\end{tabular}

Note. IHE: Institution of Higher Education.

Source: The authors.

The $\mathrm{PhD}$ graduates, $47.1 \%$ obtained an employment contract before ending the doctorate, $37.9 \%$ after ending the doctorate and $15 \%$ in the same year of completion of the course (Table 3). Regardless of the periods 
of employment, public IHE ( $\mathrm{n}=68)$, followed by private IHE $(n=9)$ were the ones that absorved the graduates.

Table 3. Period of the employment relationship of the PhD graduates. Program of the PostGraduation Program in Physical Education, Federal University of Santa Catarina, $(n=92)$.

\begin{tabular}{lcccccc}
\hline & \multicolumn{7}{c}{ Link period $^{*}$} \\
\cline { 2 - 8 } $\begin{array}{l}\text { Employee relation- } \\
\text { ship }\end{array}$ & $\begin{array}{c}\text { In the same year of } \\
\text { the term } \\
(\mathrm{n}=13)\end{array}$ & $\begin{array}{c}\text { Before finishing the } \\
\text { PhD } \\
(\mathrm{n}=41)\end{array}$ & $\begin{array}{c}\text { After completing the } \\
\text { PhD } \\
(\mathrm{n}=33)\end{array}$ \\
\cline { 2 - 8 } & $\mathrm{n}$ & $\%$ & $\mathrm{n}$ & $\%$ & $\mathrm{n}$ & $\%$ \\
\hline Public IHE & 10 & 76.9 & 29 & 70.7 & 29 & 87.9 \\
Foreign instituions & - & - & 01 & 2.4 & 01 & 3.0 \\
Federal Institutes & 01 & 7.7 & 03 & 7.3 & 01 & 3.0 \\
Private IHE & 01 & 7.7 & 06 & 14.6 & 02 & 6.1 \\
Private schools & - & - & 01 & 2.4 & - & - \\
Public schools & - & - & 01 & 2.4 & - & - \\
Freelance & 01 & 7.7 & - & - & - & - \\
\hline
\end{tabular}

Note. IHE: Institution of Higher Education. * Difference between the year of the employment relationship and the year of the end of the PhD course.

Source: The authors.

Throughout the researched graduates formative trajectory, the doctoral thesis titles $(n=41)$ and master's degrees $(n=40)$ were higher in Physical Activity and Health. In graduation, the conclusion work was more frequent in Biodynamic of Human Performance area $(n=24)$ (Figure 1). In addition, $48.9 \%(n=45)$ of the graduates changed at least once from studie area, $44.6 \%(n=41)$ remained in the same area and $6.5 \%(n=6)$ investigated in different areas during undergraduate, masters and doctoral courses.

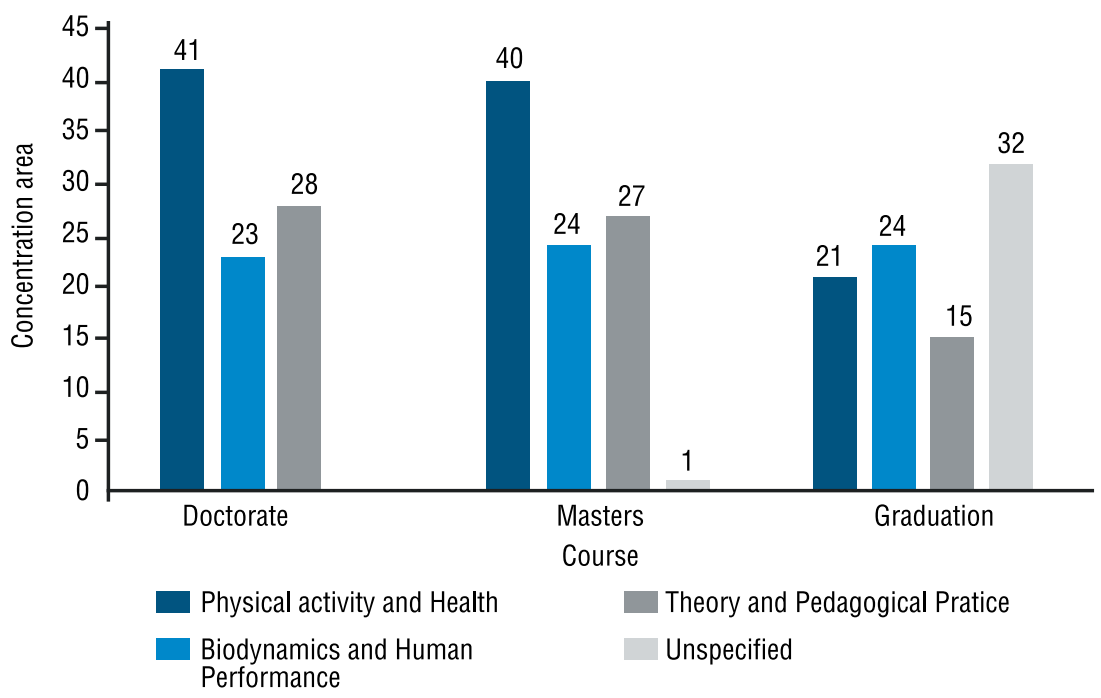

Figure 1. Concentration areas of thesis, dissertations and monographs $\mathrm{PhD}$ graduate. PostGraduation Program in Physical Education, Federal University of Santa Catarina $(n=92)$.

In the graduate's curriculum, 157 studies were identified, being more than $50 \%$ in the Physical Activity and Health area, followed by Theory and 
Pedagogical Practice (25.5\%) and Biodynamics and Human Performance (17.8\%). Researches in which graduates were coordinators are also in greater numbers in the Physical Activity and Health area (Table 4).

Table 4. Areas of concentration of the researches of the graduates of the PhD. Program of the Post-Graduation Program in Physical Education, Federal University of Santa Catarina, $(n=92)$.

\begin{tabular}{lcccccccc}
\hline & & \multicolumn{5}{c}{ Performance $^{* *}$} \\
\cline { 3 - 9 } Areas of concentration of & Total $^{*}$ & $\mathrm{n}(\%)$ & & Coordinatiors & Integrant & Unspecified \\
\cline { 3 - 9 } & & $\mathrm{n}$ & $\%$ & $\mathrm{n}$ & $\%$ & $\mathrm{n}$ & $\%$ \\
\hline Phe researches & $89(56.7)$ & 38 & 42.7 & 26 & 29.2 & 25 & 28.1 \\
Theory and Pedivity and Health & $40(25.5)$ & 23 & 57.5 & 6 & 15.0 & 11 & 27.5 \\
Biodynamics and Human Performance & $28(17.8)$ & 11 & 39.3 & 12 & 42.9 & 5 & 17.9 \\
\hline
\end{tabular}

Note. * Total: number of surveys identified by area of concentration; ${ }^{* *}$ Number of graduates according to research performance (coordinator or research member).

Source: The authors.

\section{DISCUTION}

It was analyzed that more than half of the doctorates in the period from 2006 to 2018 obtained scholarship from the development agencies. Approximately one-third of the graduates held doctorate exchange in foreign institutions and less than 20\% joined in postdoctoral. Mostly, the $\mathrm{PhD}$ graduates engaged in teaching career at higher education, including before the doctorate end. The insertion in the public IHE showed a greater amount of links before the doctorate conclusion, in the same year of the course termination and after the doctorate conclusion.

The postgraduate scenario in physical education showed that continuing education in postdoctoral stages has been a demand for a reduced number of graduates, as evidenced in other programs in Brazi $1^{15}$. However, most of them engage in teaching career before they finish the course, which may facilitate their subsequent insertion in the job market due the opportunities presented to the students during the course period ${ }^{12}$.

The possibility of entering in higher education is a constant goal, so expanding vocational training and the entry of qualified professionals at this level of education can contribute to the quality indices of education ${ }^{16,17}$. Milan et al. ${ }^{15}$ reinforce that the teaching performance valorization makes this a competitive area, bringing to the postgraduate scenario the constant search for best qualification. Nevertheless, the search for short-term experiences encourages graduates to take a course immediately one after the other, and this is clearly a market perspective ${ }^{15}$.

The career insertion in higher education occurs together with the research context in detriment to teaching ${ }^{18,19}$. In this way, some studies point to research as one of the areas with the greatest tendency, and this market positioning may cause the postgraduate teaching learning itself to be placed in the background ${ }^{12,20}$. Although the present study did not focus on the analysis of the hours distribution in the teaching activities, research, 
extension and administration of doctoral professors in public universities, it was observed that approximately half of the investigated graduates are engaged in research in their research units, teaching (as coordinators or members), especially in the Physical Activity and Health and Theory and Pedagogical Practice.

Regarding scholarships granted and the period of exchange doctoral training carried out by graduates of the from 2006 to 2018, one third were in foreign institutions, and less than $20 \%$ did postdoctoral studies. The graduates engaged in the teaching career of Higher Education, even before the end of the course. After completing the course, the highest admission was in public institutions, as observed in the Physical Education program of University of São Paulo (USP), with 65\% of graduates enrolled in public IHE ${ }^{15}$. Fact was similarly evidenced by Milan et $a 1 .{ }^{12}$ when analyzing the antecedent and current scenarios of professional intervention of graduates of the master's and doctoral courses in Physical Education of the Federal University of Santa Catarina in the period of 2006 to 2013. Few are those that act autonomously, without links which seems to reflect in the programs recommended in the National Postgraduate Plan 2011-2020 as a goal for the labor market ${ }^{2,3}$.

As for the areas of concentration in the formative trajectory of $\mathrm{PhD}$ graduates, Physical Activity and Health was more frequent in the titles of thesis dissertations and monographs, followed by Theory and Pedagogical Practice and Biodynamics and Human Performance. When investigating the professional insertion and continuing education of graduates in the Physical Education course, Salles, Farias and Nascimento ${ }^{21}$ identified that most of the bachelor's degree, $43 \%$ of the investigated, showed interest in area of Physical Activity and Health. Manoel and Carvalho ${ }^{22}$ in analyzed the criteria adopted in granting aid and resources research in the Physical Education graduate programs, and they verified that, the greater obtaining of resources and the control in the admission of people that integrate specific groups showed the hegemony of certain lines of research. This fact in function of the needs and governmental investments, justifying the predominance of the area of Physical Activity and Health in the national context ${ }^{22}$.

The formative trajectory of the graduates of the $\mathrm{PhD}$ was have different areas of concentration, indicates that the specialization in a certain area does not seem to be an exclusivity in the formation. In addition, the growth of research and methods can support 'thematic exchanges', favoring interdisciplinary in different areas. Consequently, this academic scope can promote different institutional partnerships, as well as qualification in research methods in the areas of knowledge. In fact, there is a reinforcement of the belief that the postgraduate research practice provides the dialogue of knowledge produced and shared, aiding the formation process in the search for one's own conscience, identity and professional independence.

A similar situation was observed in the research projects, in which $\mathrm{PhD}$ graduates are linked. The area of concentration in Physical Activity and Health had a greater number of registered projects and a greater proportion of coordinators. The incentive and actions aimed at research in 
postgraduate programs at universities in the South of the country may be a factor that influences these academic arrangements ${ }^{7,12}$. This investment may be a positive scenario for scientific research in Brazil, since graduates have contributed to the promotion of academic areas, as evidenced in the literature ${ }^{12,15,23}$. In Brazil, postgraduate programs are one of those

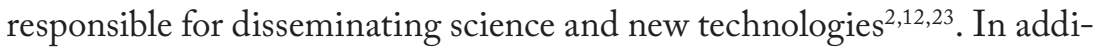
tion, research has been seen as a professional activity that permeates part of the actions of the graduates in the scope of teaching ${ }^{7,23}$.

\section{CONCLUSION}

The evidence found contributes to a scenario of expectation, regarding the insertion of $\mathrm{PhD}$ graduates in the IHE. This allows to analyze, from the context of a University of the South of Brazil, the future investments in the different research areas, and the knowledge about the professionals/teachers who are in front of the researches. However, some limitations such as the classification of the areas of concentration based on the readings of the titles of the works; the linkage profile, time and functional framework were derived from the curriculum of the graduates available on the lattes platform, which are sometimes outdated which may have influenced the data found. Some failures were observed in the completion of the curriculum, with absence of information about the title of the works, the scholarships granted by the development agencies, the nature of the undergraduate course (licentiate or bachelor's degree) and information of research projects. Thus, regarding the qualification and professional insertion of the PHD graduates' course in Physical Education of the Federal University Santa Catarina, these are mostly inserted as effective teachers in public and private IHEs. Despite the importance of continuing education in the professional success in the job market, highly dynamic and competitive, the study demonstrates that this post-doctoral experience is still performed by a small number the graduates, which may be associated with the number of vacancies and scholarships available in the different programs in the country. In the formative trajectory it was observed a higher frequency of graduates who changed their areas of concentration, at least once in the undergraduate, master's and doctorate degrees. The Physical Activity and Health was prevalent in this research, and most of the $\mathrm{PhD}$ graduates acted as coordinators. It is concluded that $\mathrm{PhD}$ formation in Physical Education seems to draw a professional profile with chances of insertion in higher education and with engagement in scientific investigations.

\section{COMPLIANCE WITH ETHICAL STANDARDS}

\section{Funding}

This research did not receive any specific grant from funding agencies in the public, commercial, or not-for-profit sectors. This study was funded by the authors. 


\section{Conflict of interest statement}

The authors have no conflict of interests to declare.

\section{Author Contributions}

Conception and design of the study: SWM. Data collection and tabulation: SWM, PFS and AAC. Data analysis: SWM. Article Writing: All Authors. All authors read and approved the final version of the manuscript.

\section{REFERENCES}

1. Balbachevsky E. A pós-graduação no Brasil: novos desafios para uma política bem-sucedida. In: Brock. C.; Schwartzman, S. Os desafios da educação no Brasil. Rio de Janeiro: Nova Fronteira; 2005, p. 275-304.

2. Brasil. Ministério da Educação. Coordenação de Aperfeiçoamento de Pessoal de Nível Superior Plano Nacional de Pós-Graduação - PNPG 2011-2020. Coordenação de Pessoal de Nível Superior. Brasília, DF: CAPES, 2010. Disponível em: https://www.capes.gov.br/images/stories/download/Livros-PNPG-Volume-IMont.pdf [2018 dec 09].

3. Brasil. Portaria $n^{\circ} 321$, de 5 de abril de 2018. Dispõe sobre a avaliação da pósgraduação stricto sensu. 2018. Disponível em: https://capes.gov.br/images/stories/ download/legislacao/06042018-Portaria-MEC-n-321-de-5-de-abril-de-2018.pdf [2018 dec 09].

4. Ministério da Educação. Documento de área: área 21 Educação Física. Coordenação de Aperfeiçoamento de Pessoal de Nível Superior- CAPES, 2016. Disponível em: http://www.capes.gov.br/images/documentos/Documentos_de_area_2017/21_ efis_docarea_2016.pdf. [2018 dec 09].

5. Ministério da Educação. Relatório de Avaliação de Educação Física. Avaliação Quadrienal de 2017. Coordenação de Aperfeiçoamento de Pessoal de Nível Superior- CAPES, 2017. Disponível em: http://www.capes.gov.br/images/stories/ download/avaliacao/relatorios-finais-quadrienal-2017/20122017-EDUCACAOFISICA-quadrienal.pdf [2018 dec 09].

6. Marchlewski C, Silva PMda, Soriano JB. A influência do sistema de avaliação Qualis na produção de conhecimento científico: algumas reflexões sobre a Educação Física. Motriz: J Phys Ed 2011;17(1): 104-116.

7. Moreira EC, Tojal JBAG. A formação em Programas de Pós-Graduação Strictu Sensu em Educação Física: preparação docente versus preparação para pesquisa. Mov 2009; 4: 127-145.

8. Hortale VA, Moreira COF, Bochner R, Leal C. Trajetória profissional de egressos de cursos de doutorado nas áreas da saúde e biociências. Rev Saúde Pública 2014; 48 (1): $1-9$.

9. Freitas MAO, Demarchi GSS, Rossit RAS. Educação Interprofissional na pósgraduação stricto sensu: o olhar dos egressos. Interface 2018; 22(2): 1647-1659.

10. Senger MH, Campos MCG, Servidoni MFCP, Passeri SMRR, Toro IFC, et al. Trajetória profissional de egressos do curso de Medicina da Universidade de Campinas (Unicamp), São Paulo, Brasil: o olhar do ex-aluno na avaliação do programa. Interface 2018; 22 (1): 1443-1455.

11. Gentil RN. Situação profissional de doutores egressos dos Programas de Pósgraduação em Educação Física. [Dissertação de Mestrado- Programa de Pósgraduação em Educação Física]. Florianópolis (SC): Universidade Federal de Santa Catarina; 2016.

12. Milan FJ, Pereira MPVC, Lacerda EB, Folle A, Nascimento JV, Farias GO. Â bitos de atuação profissional de egressos dos cursos de pós-graduação em educação física da UFSC. J Phys Educ 2019; 30(1): 1-11. 
13. Brasil. Ministério da Educação. Web site. Disponível em: https://sucupira.capes. gov.br/sucupira/public/consultas/coleta/programa/quantitativos/quantitativoles.js f?areaAvaliacao=21\&areaConhecimento=40900002. [2019 apr 09].

14. Silva IC, Farias LA, Santos W. Pós-graduação e produção científica: a teoria do capital humano e as demandas do setor produtivo. Filosofia Educ 2017; 8(3):142-168.

15. Bastos FC, Sá MR, Rocco J, Ary J. 40 anos da Pós-graduação da EEFE-USP: sua contribuição para a formação de recursos humanos para a docência no ensino superior. Rev Bras Educ Fís Esporte 2017; 31:89-96.

16. Proni MW. Universidade, profissão Educação Física e o mercado de trabalho. Motriz: J Phys Ed 2010; 16(3):788-798.

17. Quadros H, Afonso M, Ribeiro J. O Cenário da Pós-Graduação em Educação Física: Contextos e possibilidades na região sul do Brasil. Rev Bras Ativ Fís Saúde 2013;18(5): 576-576.

18. Zaidan S, Caldeira MAS, Oliveira BJ, Silva PGC. Pós-Graduação, saberes e formação docente: uma análise das repercussões dos cursos de mestrado e doutorado na prática pedagógica de egressos do Programa de Pós-Graduação da Faculdade de Educação da UFMG (1977-2006). Educ Rev 2011; 27 (1): 129-160.

19. Moreira ML, Velho L. Trajetória de egressos da pós- graduação do Instituto Nacional de Pesquisas Espaciais: uma ferramenta para avaliação. Aval 2012; 17 (1): 255-288.

20. Tani Go. Professional preparation in physical education: changing labor market and competence. Motriz: Rev Educ Física 2013;19 (3): 552-557.

21. Salles WN, Farias GO, Nascimento JV. Inserção profissional e formação continuada de egressos de cursos de graduação em Educação Física. Rev Bras Educ Fís Esporte 2015; 29 (3): 475-486.

22. Manoel EJ Carvalho YM. Pós-graduação na educação física brasileira: a atração (fatal) para a biodinâmica. Educ Pesqui 2011; 37(2):389-406.

23. Moreira EC, Tojal JBAG. Prioridades dos programas de Pós-graduação stricto sensu em educação física: a visão dos egressos. Rev Bras Ciênc Esporte 2013; 35 (1):161-178.

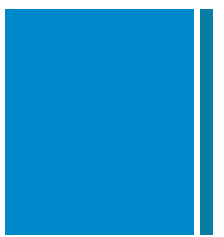

Corresponding autho

Sofia Wolker Manta

Street: Avenida dos Salmões 874

Neighborhood: Jurerê Internacional.

Zip Code: 88.053-365.

City: Florianópolis. State: Santa Catarina.

E-mail: sofiawolker@gmail.com 